\title{
Comparison of wheat and safflower cultivation areas in terms of total carbon and some soil properties under semi-arid climate conditions
}

\author{
B. Turgut \\ Artvin Coruh University, Forestry Faculty, Department of Soil and Ecology, Artvin, Turkey \\ Correspondence to: B. Turgut (bturgut@artvin.edu.tr) \\ Received: 10 February 2015 - Published in Solid Earth Discuss.: 6 March 2015 \\ Revised: 26 May 2015 - Accepted: 31 May 2015 - Published: 17 June 2015
}

\begin{abstract}
The aim of this study was to compare the soils of the wheat cultivation area (WCA) and the safflower cultivation area (SCA) within semi-arid climate zones in terms of their total carbon, nitrogen, and sulphur contents, particle size distribution, aggregate stability, organic matter content, and $\mathrm{pH}$ values. This study presents the results from the analyses of 140 soil samples taken at two soil layers (0-10 and $10-20 \mathrm{~cm}$ ) in the cultivation areas. At the end of the study, it was established that there were significant differences between the cultivation areas in terms of soil physical properties such as total carbon (TC), total nitrogen (TN), total sulphur (TS) contents and $\mathrm{pH}$, while only the TN content was significantly different between the two soil layers. Moreover, significant differences were identified between the cultivation areas in terms of soil physical properties including clay and sand contents, aggregate stability, and organic matter content, whereas the only significant difference found among the soil layers was that of their silt content. Since safflower contains higher amounts of biomass than wheat, we found higher amounts of organic matter content and, therefore, higher amounts of TN and TS content in the soils of the SCA. In addition, due to the fact that wheat contains more cellulose - which takes longer to decompose - the TC content of the soil in the WCA was found to be higher than that in the SCA. The results also revealed that the WCA had a higher carbon storage capacity.
\end{abstract}

\section{Introduction}

Soil-forming process have significant effects on soil properties (Ubalde et al., 2011). One such process is the agricultural management practice. It is a well-known fact that different agricultural management practices such as soil tillage, irrigation, and crop design cause changes in physical and chemical properties of soils, even though the soils are formed under the same conditions (Özgöz et al., 2012; Reynolds et al., 2007; Valpassos et al., 2001).

Plants have direct and indirect effects on the soil properties (Schjønning et al., 2004). Plant roots' influence on physical soil properties such as aggregate formation, compaction, and infiltration rate can be described as the direct effects of plants (Reid and Goss, 1981; Miller and Jastrow, 1990; Angers and Caron, 1998; Milleret et al., 2009). Having completed their natural life cycles, plants begin to decompose in the soil and thereby become one of the main sources of organic matter, which in turn provides a positive contribution to the physical, chemical, and biological properties of soils (Karaman et al., 2013; Rowell, 1994; Turgut and Aksakal, 2011; Wang et al., 2014; Huang et al., 2015).

Crop residues - such as the components dried up or fallen from the plants onto the ground during the cultivation season or those left underground during the harvest season - along with their roots under the soil constitute a significant portion of the organic material in the soil (Schjønning et al., 2004). For this reason, plant types with advanced vegetative components and root distribution contribute more greatly in terms of organic matter contents. In addition, the main sources of carbon $(\mathrm{C})$ and nitrogen $(\mathrm{N})$ found in the soil also come from such crop residues (Karaman, 2012). However, since the de- 
composition of cellulose and lignin - found richly in some types of plants such as wheat - takes longer than other components, it is observed that the soils of such cultivation areas are rich in $\mathrm{C}$ content and poor in $\mathrm{N}$ content compared to other cultivation lands (Benbi et al., 2015; Kramer et al., 2002; Srinivasarao et al., 2014; Zhengchao et al., 2013; Kuzyakov and Domanski, 2000).

The total carbon content of soils is highly important due to being both an indicator of the overall soil quality (Rowell, 1994; Schjønning et al., 2004) and relevant to climate change (Wan et al., 2011; Muñoz-Rojas et al., 2012; ParrasAlcántara et al., 2015). Storage of carbon in the soil involves the process of plants' carbon intake from the atmosphere and the usage of it in photosynthesis, and the transfer of the biomass carbon into the soil in the form of humus (Srinivasarao et al., 2014).

Literature shows that there have been many studies investigating the effects of different cropping systems or soil cultivation practices on the total carbon content (Karaman et al., 2013; Koga et al., 2011; Debasish-Saha et al., 2012; Muñoz-Rojas et al., 2012; Parras-Alcántara et al., 2013; Fialho and Zinn, 2014; Srinivasarao et al., 2014), whereas only little research has been completed on the comparison of lands formed under the same conditions but allocated to different plant cultivations. This study attempts to compare the soils devoted to wheat and safflower cultivation in semi-arid climate zones in respect to some of their physical and chemical properties, with particular attention given to their total carbon content. Since the soil's capacity to store carbon is vitally important in terms of climate change and soil fertility, it is believed that the results of this study will be useful in this particular sense.

\section{Materials and methods}

\subsection{Materials}

The study was conducted in two different experimental areas, the wheat cultivation area (WCA) and safflower cultivation area (SCA), located in the province of Eskişehir (Fig. 1). These areas have been maintained with a bread wheat (Triticum aestivum)-fallow sequence and a safflower (Carthamus tinctorius)-fallow sequence for more than 20 years (Fig. 2). In both cultivation areas, conventional tillage (moldboard plow followed disk harrowing) has been used and chemical fertilizer has been applied for 20 years. The soil at both sites is classified as a Fulvic Calcisol. Average wheat yield in the experimental area is $2.75 \mathrm{tha}^{-1}$, while average safflower yield is $0.7 \mathrm{tha}^{-1}$. The geographical coordinates of the WCA are $39^{\circ} 46^{\prime} 12.32^{\prime \prime} \mathrm{N}$ and $30^{\circ} 23^{\prime} 53.27^{\prime \prime} \mathrm{E}$, while the coordinates of the SCA are $39^{\circ} 44^{\prime} 12.88^{\prime \prime} \mathrm{N}$ and $30^{\circ} 09^{\prime} 50.51^{\prime \prime} \mathrm{E}$. Moreover both areas rely on a precipitationbased agricultural system. The total annual precipitation rate in the experimental areas is $370 \mathrm{~mm}$, classified as a semiarid climate zone. While the lowest temperature in the ar- eas is $-0.1{ }^{\circ} \mathrm{C}$ in January, the highest temperature is $21.7^{\circ} \mathrm{C}$ in July. The soils in both experimental areas were formed on non-decomposed quaternary material (MRE Earth Science Portal, 2014). Both areas of cultivation are situated on a straight slope, and the elevations from the sea level are 812 and $1018 \mathrm{~m}$ for the WCA and the SCA, respectively.

\subsection{Methods}

\subsubsection{Sampling pattern and soil analyses}

In order to identify the soil properties of the experimental areas, the WCA and SCA were divided into $10 \times 10 \mathrm{~m}$ grids, and 140 disturbed soil samples were taken from 0 10 and $10-20 \mathrm{~cm}$ depths at each of the 35 points where the grids intersect. Total carbon (TC), total nitrogen (TN) and total sulphur (TS) contents of the soils were identified using an elemental analysis device (an Elementar vario MACRO cube CHNS elemental analyzer). A wet combustion method (Sparks et al., 1996), Yoder wet-sieving method (Dane et al., 2002), and hydrometer method (Gee et al., 1986) were used for identifying the organic matter content, aggregate stability (1-2 mm aggregates), and particle size distribution of the soils. The $\mathrm{pH}$ values of the soils were measured in the $1: 2.5$ soil-water suspension (Conklin, 2005).

\subsubsection{Statistical analyses}

Descriptive statistics, including averages, standard deviation, minimum and maximum values, and the coefficient of variation were determined for all the studied soil properties. The Shapiro-Wilk W test was used for determining whether soil properties fit normal distribution. Moreover, the analysis of variance was applied in determining the differences between the cultivation areas and the soil layers in terms of soil properties. JMP 5.0 package software was used in conducting statistical analyses (JMP, 2007).

\section{Results and discussion}

\subsection{Fundamental characteristics of the soils in the experimental areas}

As a result of the elemental analysis, it was established that TC content was the highest in the soil, while TS was the least. Analyses showed that the soil texture for the WCA was clay. In addition, the organic matter content, the aggregate stability, and $\mathrm{pH}$ were classified as intermediate, very-good and mid-level alkaline, respectively. As for the SCA, the results revealed that the texture was that of clay and clay loam, and was considered to be very good in terms of aggregate stability, its high organic matter content and being light alkaline in terms of $\mathrm{pH}$. The coefficient of variation (CV) values for studied soil properties were less than $50 \%$, while the lowest $\mathrm{CV}$ was observed for $\mathrm{pH}$ and the highest was observed for the TS. Moreover the Shapiro-Wilk W test results indicated 

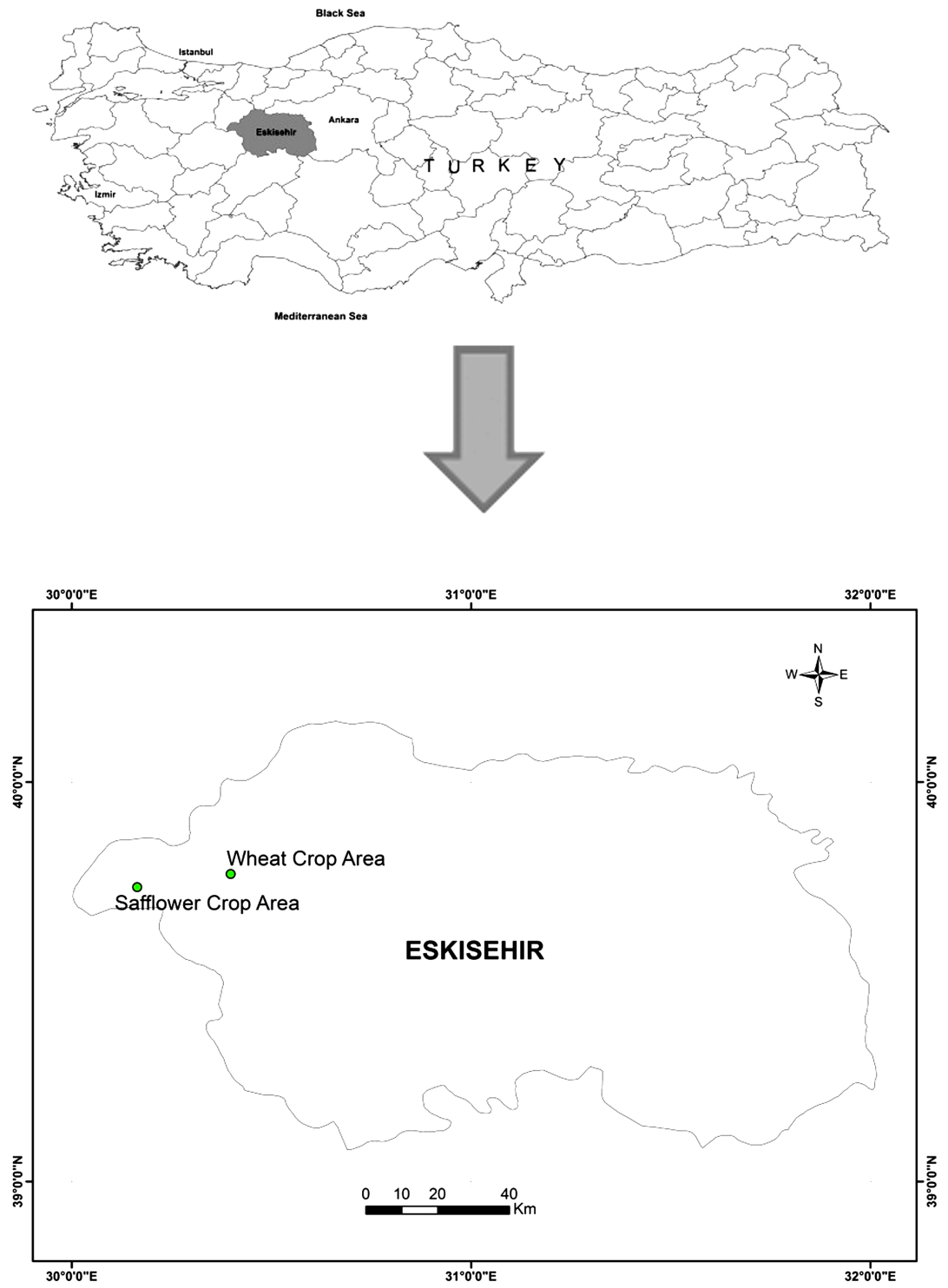

Figure 1. The locations of studied areas.

that all the observed soil properties were normally distributed (Table 1).

\subsection{Comparison of the soil properties}

\subsubsection{Particle size distribution}

The results of particle size analysis showed that the clay and silt contents were significantly greater in the WCA, while the sand content was significantly greater in the SCA. As for soil layers, the differences in terms of clay and sand content were not significant, while silt content was significantly greater in the $0-10 \mathrm{~cm}$ layer (Table 2). The particle size distribution is regarded as the least affected soil property in agricultural management practices (Karaman et al, 2012). For this reason, it is believed that the difference between the cultivation areas, in terms of particle size distribution, was caused by the parent material differences where the soils were originally formed (Table 2).

\subsubsection{Organic matter content}

The organic matter content was found to be significantly greater in the SCA than the WCA (Table 2). It is well-known that the main source of organic matter in soil is plant and animal residue (Baldock and Nelson, 2000; Karaman et al., 2012), and that any amount of organic substance resulting from a plant is directly proportionate to its biomass (Sollins et al., 1996; Jaiarree et al., 2011; Novara et al., 2013). The reason for the greater organic matter content in the SCA than 

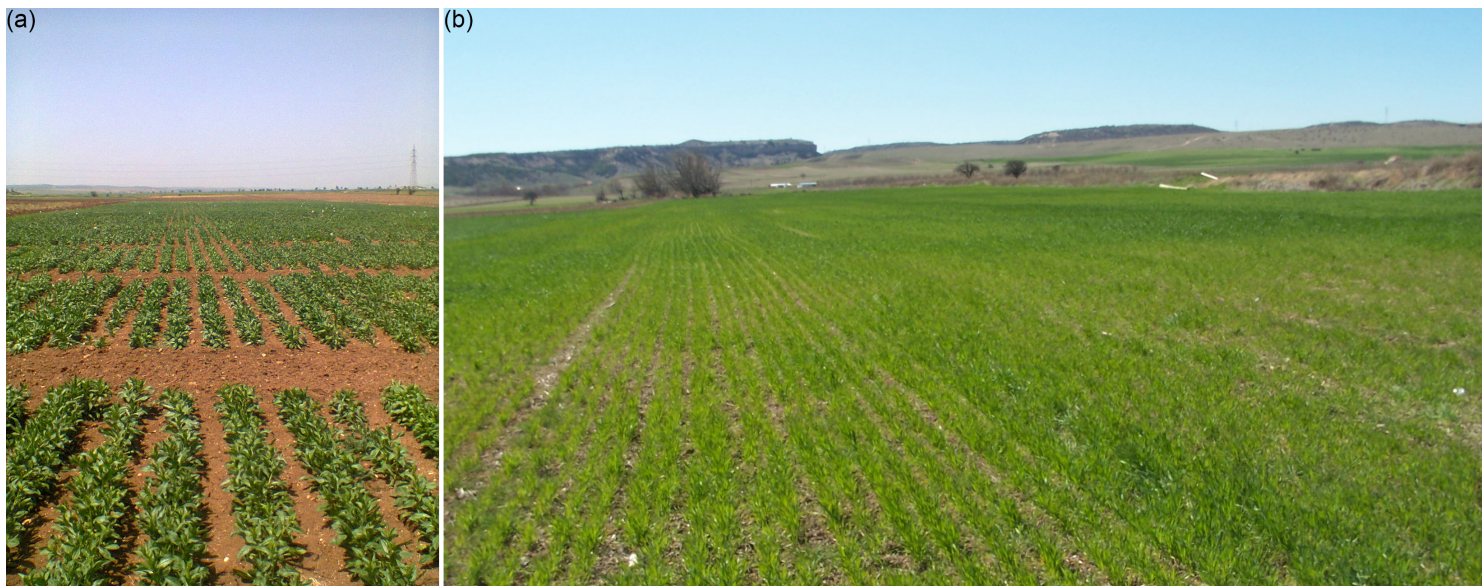

Figure 2. Scenes from the safflower (a) and wheat (b) cultivation areas.

Table 1. Descriptive statistics of the soil properties.

\begin{tabular}{llllll}
\hline Variables & Mean & Minimum & Maximum & $\begin{array}{l}\text { Coefficient of } \\
\text { variations (\%) }\end{array}$ & $\begin{array}{l}\text { Shapiro-Wilk } \\
\text { W Test }\end{array}$ \\
\hline Total carbon \% & $2.10 \pm 0.41$ & 1.48 & 2.73 & 19.50 & $0.984 \mathrm{~ns}$ \\
Total nitrogen \% & $0.15 \pm 0.04$ & 0.09 & 0.22 & 26.67 & $0.976 \mathrm{~ns}$ \\
Total sulphur \% & $0.017 \pm 0.008$ & 0.003 & 0.038 & 47.05 & $0.977 \mathrm{~ns}$ \\
Organic matter content \% & $3.58 \pm 0.89$ & 2.21 & 5.86 & 24.86 & $0.978 \mathrm{~ns}$ \\
pH & $7.92 \pm 0.36$ & 7.34 & 8.41 & 4.55 & $0.998 \mathrm{~ns}$ \\
Aggregate stability \% & $67.52 \pm 15.67$ & 29.60 & 92.98 & 23.20 & $0.975 \mathrm{~ns}$ \\
Clay content \% & $43.61 \pm 6.74$ & 28.40 & 54.94 & 15.46 & $0.981 \mathrm{~ns}$ \\
Silt content \% & $32.01 \pm 3.09$ & 22.94 & 38.90 & 9.65 & $0.987 \mathrm{~ns}$ \\
Sand content \% & $24.29 \pm 7.03$ & 11.92 & 38.43 & 28.94 & $0.992 \mathrm{~ns}$ \\
\hline
\end{tabular}

ns: non-significant.

in the WCA can be explained by the fact that the biomass amount of the safflower (Lenssen et al., 2007; Schillinger et al., 2007) and its residues remaining after the harvest season (Krupinsky et al., 2006) are greater than the wheat. No significant difference was observed among the soil layers in terms of organic matter content (Table 2).

\subsubsection{Total carbon}

Average TC was significantly greater in the WCA compared to the SCA (Table 2). The fact that the wheat contains a higher amount of cellulose (59\%) than safflower contains(40\%) (Del Río et al., 2012; Schjønning et al., 2004; Smith, 1996), and that the decomposition rate of cellulose is fairly slow (Boswell, 1941) can help explain the higher rates of TC content in the WCA. Another reason for the higher rates of carbon content in the WCA can be associated with a higher rate of $\mathrm{C}: \mathrm{N}$ ratio for the wheat compared to the safflower. Despite the absence of any study directly comparing the TC contents of both wheat and safflower cultivation areas, studies comparing the soils of wheat with other crop species also reported greater $\mathrm{TC}$ and $\mathrm{C}: \mathrm{N}$ ratios for wheat
Table 2. Summary of ANOVA for soil properties.

\begin{tabular}{lllll}
\hline Soil properties & \multicolumn{2}{c}{ Cultivation areas } & \multicolumn{2}{c}{ Soil layers } \\
\cline { 2 - 5 } & WCA & SCA & $0-10 \mathrm{~cm}$ & $10-20 \mathrm{~cm}$ \\
\hline Sand content (\%) & $18.30 \mathrm{~B}$ & $30.64 \mathrm{~A}$ & 24.47 & 24.48 \\
Silt content (\%) & $32.50 \mathrm{a}$ & $31.27 \mathrm{~b}$ & $32.56 \mathrm{~A}$ & $31.22 \mathrm{~B}$ \\
Clay content (\%) & 49.20 A & $38.08 \mathrm{~B}$ & 42.97 & 44.31 \\
Organic matter (\%) & $2.74 \mathrm{~B}$ & $4.43 \mathrm{~A}$ & 3.59 & 3.59 \\
Total carbon (\%) & 2.491 A & $1.704 \mathrm{~B}$ & 2.104 & 2.091 \\
Total nitrogen (\%) & $0.117 \mathrm{~B}$ & $0.183 \mathrm{~A}$ & $0.153 \mathrm{a}$ & $0.147 \mathrm{~b}$ \\
Total sulphur (\%) & $0.010 \mathrm{~B}$ & $0.024 \mathrm{~A}$ & 0.016 & 0.017 \\
Aggregate stability (\%) & 62.82 B & $73.62 \mathrm{~A}$ & 70.16 & 73.62 \\
pH & 8.24 A & $7.57 \mathrm{~B}$ & 7.89 & 7.91 \\
\hline
\end{tabular}

Means with capital and small letters indicate significant differences; 0.01 and 0.05 , respectively. (WCA: wheat cultivation area; SCA: safflower cultivation area).

(Benbi et al., 2015; Bolinder et al., 1997; Koga et al., 2011). TC content was greater in the topsoil layer but this difference was not significant (Table 2). 


\subsubsection{Total nitrogen}

The TN content was found to be greater in the soils of the SCA than the WCA (Table 2), most probably due to the higher soil organic matter content recorded in the former site, as organic nitrogen is converted into mineral nitrogen as a result of the decomposition of organic materials (Rowell, 1994). Previous studies under different climate conditions and management practices also reported similar findings of positive correlation between organic matter and $\mathrm{TN}$ in soils. (Barrett and Burke, 2000; Filep and Rékási, 2011; ParrasAlcántara et al., 2013; Hu et al., 2014; Parras-Alcántara and Lozano-García, 2014). In respect to the soil layers, the analyses revealed that the TN content was significantly greater in the topsoil (Table 2), which is similar to the findings of previous studies (Parras-Alcántara et al., 2013; Yu and Jia, 2014). The fundamental reason for this difference can be related to the rate of decomposition being faster on the top surface due to better ventilation conditions.

\subsubsection{Total sulphur}

Similar to the TN content, the TS content in the SCA was significantly greater than that in the WCA (Table 2). Literature shows that a significant portion of the sulphur component in soil consists of organic sulphur resulting from the decomposition of organic matter (Karaman, 2012; Janzen and Ellert, 1998), and for this reason it is anticipated that the SCA with rich organic matter content should also yield a higher TS content. Moreover, it was established that there were no significant differences among the soil layers in terms of TS content (Table 2).

\subsubsection{Aggregate stability}

It was determined that the aggregate stability values of the SCA were significantly higher than the WCA (Table 2). Low aggregate stability can generally be related to deterioration in the structural properties of the soil generally caused by some agricultural practices, including the use of heavy machinery and tillage under unsuitable soil moisture conditions in agricultural fields (Dilkova et al., 2002). In order to promote the aggregate stability in such areas, it is suggested that the organic substance content in the soil be increased by way of fertilization and scattering of plant residues in the field (Lal, 1998; Swindale, 1998). As explained above, the SCA had greater organic matter content than the WCA, considered as one of the factors for the higher aggregate stability. Moreover, literature shows that safflower cultivation improves the physical properties of the soil (Jayawardane and Chan, 1994) through its deep roots (Wachsmann et al., 2008) and high organic residues, yielding higher aggregate stability values in the SCA. In addition, Nichols and Toro (2011) reported that when safflower is used in crop rotation sequences, higher aggregate stability values were found over the wheat- fallow crop rotation sequence. No significant difference was detected among the soil layers in terms of aggregate stability (Table 2).

\subsection{7 pH}

It was established that the $\mathrm{pH}$ values of the SCA were significantly lower than the WCA (Table 2). The reasons for this low $\mathrm{pH}$ in the SCA may be associated with two processes including the decomposition of organic matter and the emerging of organic acids and carbonic acids, produced by dissolving $\mathrm{CO}_{2}$ in the soil solution following root and microbial respiration (Karaman et al., 2013; Rowell, 1993). These reasons are parallel to our findings since the analyses revealed higher organic matter content in the SCA, a main factor which lowers $\mathrm{pH}$, compared to the WCA. No significant difference was observed among the soil layers in terms of $\mathrm{pH}$ values (Table 2).

\section{Conclusions}

This study was conducted to examine the soil properties of the wheat and safflower cultivation areas formed under similar parent material and climate conditions. The results revealed that the organic matter content of the soils has a determining effect on the $\mathrm{TN}, \mathrm{TS}, \mathrm{pH}$, and aggregate stability. Due to the higher ratio of organic matter content in the SCA, we found that the TN, TS, and aggregate stability values were all significantly greater in the SCA than the WCA, while the $\mathrm{pH}$ was significantly lower in the SCA. As for the amount of TC content, however, it was found that the quality of the organic matter was more important than its quantity. The fact that the wheat has higher ratios of lignin and cellulose content results in a slower decomposition rate and a higher TC content in the WCA as compared to the SCA. Moreover, while the silt and TN contents of the soils were found to be significantly greater in the bottom soil layer, the rest of the soil properties were measured to be similar among the soil layers.

Edited by: A. Cerdà

\section{References}

Angers, D. A. and Caron, J.: Plant-induced changes in soil structure: processes and feedbacks, in: Plant-Induced Soil Changes: Processes and Feedbacks, edited by: Van Breemen, N., Springer Netherlands, Dordrecht, the Netherlands, 55-72, 1998.

Baldock, J. A. and Nelson, P.: Soil organic matter, in: Handbook of Soil Science, edited by: Sumner, M. E., CRC Press, Boca Raton, FL, USA, 2000.

Barrett, J. E. and Burke, I. C.: Potential nitrogen immobilization in grassland soils across a soil organic matter gradient, Soil Biol. Biochem., 32, 1707-1716, doi:10.1016/S0038-0717(00)000894, 2000 
Benbi, D. K., Brar, K., Toor, A. S., and Singh, P.: Total and labile pools of soil organic carbon in cultivated and undisturbed soils in northern India, Geoderma, 237, 149-158, 2015.

Bolinder, M. A., Angers, D. A., and Dubuc, J. P.: Estimating shoot to root ratios and annual carbon inputs in soils for cereal crops, Agr. Ecosyst. Environ., 63, 61-66, doi:10.1016/S01678809(96)01121-8, 1997.

Boswell, J. G.: The biological decomposition of cellulose, New Phytol., 40, 20-33, 1941.

Conklin, A. R.: Introduction to Soil Chemistry: Analysis and Instrumentation, Wiley, Hoboken, NJ, USA, 2005.

Dane, J. H., Topp, C., Campbell, G. S., Horton, R., Jury, W. A., Nielsen, D. R., van Es, H. M., Wierenga, P. J., and Topp, G. C.: Methods of Soil Analysis: Part 4 - Physical methods, Soil Science Society of America, Inc., Madison, WIS, USA, 2002.

Debasish-Saha, Kukal, S. S., and Bawa, S. S.; Soil organic carbon stock and fractions in relation to land use and soil depth in the degraded Shiwaliks Hills of lower Himalayas, Land Degrad. Dev., 25, 407-416, 2012.

Del Río, J. C., Rencoret, J., Prinsen, P., Martínez, A. N. T., Ralph, J., and Gutieìrrez, A.: Structural characterization of wheat straw lignin as revealed by analytical pyrolysis, 2D-NMR, and reductive cleavage methods, J. Agr. Food Chem., 60, 5922-5935, 2012.

Dilkova, R., Jokova, M., Kerchev, G., and Kercheva, M.: Aggregate stability as a soil quality criterion, in: Proceeding of the 7. International Meeting on Soils with Mediterranean Type of Climate, Bari, Italy, 23-28 September 2001, 50, 305-312, 2002.

Fialho, R. C. and Zinn, Y. L.: Changes in soil organic carbon under eucalyptus plantations in Brazil: a comparative analysis, Land Degrad. Dev., 25, 428-437, doi:10.1002/ldr.2158, 2014.

Filep, T. and Rékási, M.: Factors controlling dissolved organic carbon (DOC), dissolved organic nitrogen $(\mathrm{DON})$ and $\mathrm{DOC}=\mathrm{DON}$ ratio in arable soils based on a dataset from Hungary, Geoderma, 162, 312-318, doi:10.1016/j.geoderma.2011.03.002, 2011.

Gee, G. W., Bauder, J. W., and Klute, A.: Particle-Size Analysis, Methods of Soil Analysis, Part 1. Physical and Mineralogical Methods, Soil Since Society of America, Inc., Madison, WIS, USA, 1986.

Hu, K., Wang, S., Li, H., Huang, F., and Li, B.: Spatial scaling effects on variability of soil organic matter and total nitrogen in suburban Beijing, Geoderma, 226, 54-63, doi:10.1016/j.geoderma.2014.03.001, 2014.

Huang, M., Liang, T., Wang, L., and Zhou, C.: Effects of no-tillage systems on soil physical properties and carbon sequestration under long-term wheat-maize double cropping system, Catena, 128, 195-202, doi:10.1016/j.catena.2015.02.010, 2015.

Jaiarree, S., Chidthaisong, A., Tangtham, N., Polprasert, C., Sarobol, E., and Tyler, S. C.: Carbon budget and sequestration potential in a sandy soil treated with compost, Land Degrad. Dev., 25, 120-129, 2011.

Janzen, H. H. and Ellert, B. H.: Sulfur dynamics in cultivated, temperate agroecosystems, in: Sulfur in the Environment, edited by: Maynard, D. G., Marcel Decker, New York, USA, 11-43, 1998.

Jayawardane, N. and Chan, K.: The management of soil physical properties limiting crop production in Australian sodic soils - a review, Aust. J. Soil Res., 32, 13-44, 1994.

JMP: JMP, Version 5.0, SAS Institute Inc., Cary, NC, USA, 19892007.
Karaman, M.: Plant Nutrition, Gubretas Guide Book Series No. 2, Detay Press, Ankara, Turkey, 2012.

Karaman, M., Brohi, A., Müftüoğlu, N., Öztaş, T., and Zengin, M.: Sustainable Soil Fertility, Detay Press, Ankara, Turkey, 2013.

Koga, N., Smith, P., Yeluripati, J. B., Shirato, Y., Kimura, S. D., and Nemoto, M.: Estimating net primary production and annual plant carbon inputs, and modelling future changes in soil carbon stocks in arable farmlands of northern Japan, Agr. Ecosyst. Environ., 144, 51-60, doi:10.1016/j.agee.2011.07.019, 2011.

Kramer, A. W., Doane, T. A., Horwath, W. R., and van Kessel, C.: Short-term nitrogen-15 recovery vs. long-term total soil $\mathrm{N}$ gains in conventional and alternative cropping systems, Soil Biol. Biochem., 34, 43-50, 2002.

Krupinsky, J. M., Tanaka, D. L., Merrill, S. D., Liebig, M. A., and Hanson, J. D.: Crop sequence effects of 10 crops in the northern Great Plains, Agr. Syst., 88, 227-254, doi:10.1016/j.agsy.2005.03.011, 2006.

Kuzyakov, Y. and Domanski, G.: Carbon input by plants into the soil, review, J. Plant Nutr. Soil Sc., 163, 421-431, 2000.

Lal, R.: Soil degradation, in: Red and Lateritic Soils, vol. 1, edited by: Sehgal, J., Blum, W. E., and Gajbhiye, K. S., Oxford and IBH Publishing CO.P.V.T. LTD, New Delhi, India, 237-253, 1998.

Lenssen, A. W., Johnson, G. D., and Carlson, G. R.: Cropping sequence and tillage system influences annual crop production and water use in semiarid Montana, USA, Field Crop. Res., 100, 3243, doi:10.1016/j.fcr.2006.05.004, 2007.

Miller, R. M. and Jastrow, J. D.: Hierarchy of root and mycorrhizal fungal interactions with soil aggregation, Soil Biol. Biochem., 22, 579-584, doi:10.1016/0038-0717(90)90001-G, 1990.

Milleret, R., Le Bayon, R. C., Lamy, F., Gobat, J. M., and Boivin, P.: Impact of roots, mycorrhizas and earthworms on soil physical properties as assessed by shrinkage analysis, J. Hydrol., 373, 499-507, 2009.

MRE Earth Science Portal: available at: http://yerbilimleri.mta.gov. tr/anasayfa.aspx (last access: 15 June 2015), 2014.

Muñoz-Rojas, M., Jordán, A., Zavala, L. M., De la Rosa, D., AbdElmabod, S. K., and Anaya-Romero, M.: Organic carbon stocks in Mediterranean soil types under different land uses (Southern Spain), Solid Earth, 3, 375-386, doi:10.5194/se-3-375-2012, 2012.

Nichols, K. A. and Toro, M.: A whole soil stability index (WSSI) for evaluating soil aggregation, Soil Till. Res., 111, 99-104, doi:10.1016/j.still.2010.08.014, 2011.

Novara, A., Gristina, L., Rühl, J., Pasta, S., D’Angelo, G., La Mantia, T., and Pereira, P.: Grassland fire effect on soil organic carbon reservoirs in a semiarid environment, Solid Earth, 4, 381-385, doi:10.5194/se-4-381-2013, 2013.

Özgöz, E., Günay, H., Önen, H., Bayram, M., and Acir, N.: Eect of management on spatial and temporal distribution of soil physical properties, J. Agr. Sci., 18, 77-91, 2012.

Parras-Alcántara, L. and Lozano-García, B.: Conventional tillage versus organic farming in relation to soil organic carbon stock in olive groves in Mediterranean rangelands (southern Spain), Solid Earth, 5, 299-311, doi:10.5194/se-5-299-2014, 2014.

Parras-Alcántara, L., Martín-Carrillo, M., and Lozano-García, B.: Impacts of land use change in soil carbon and nitrogen in a Mediterranean agricultural area (Southern Spain), Solid Earth, 4, 167-177, doi:10.5194/se-4-167-2013, 2013. 
Parras-Alcántara, L., Lozano-García, B., and Galán-Espejo, A.: Soil organic carbon along an altitudinal gradient in the Despeñaperros Natural Park, southern Spain, Solid Earth, 6, 125134, doi:10.5194/se-6-125-2015, 2015.

Reid, J. B. and Goss, M. J.: Effect of living roots of different plant species on the aggregate stability of two arable soils, J. Soil Sci., 32, 521-541, 1981.

Reynolds, W. D., Drury, C. F., Yang, X. M., Fox, C. A., Tan, C. S., and Zhang, T. Q.: Land management effects on the near-surface physical quality of a clay loam soil, Soil Till. Res., 96, 316-330, doi:10.1016/j.still.2007.07.003, 2007.

Rowell, D. L.: Soil Science: Methods and Applications, Longman Scientific \& Technical, Harlow, Essex, UK, 1994.

Schillinger, W. F., Kennedy, A. C., and Young, D. L.: Eight years of annual no-till cropping in Washington's winter wheatsummer fallow region, Agr. Ecosyst. Environ., 120, 345-358, doi:10.1016/j.agee.2006.10.017, 2007.

Schjønning, P., Elmholt, S., and Christensen, B. T.: Managing soil quality: challenges in modern agriculture, Publishing, Wallingford, UK, CABI Publishing, Cambridge, MA, USA, 2004.

Smith, J. R.: Saffower, Taylor \& Francis, The American Oil Chemist Society, Urbana, IL, USA, 1996.

Sollins, P., Homann, P., and Caldwell, B. A.: Stabilization and destabilization of soil organic matter: mechanisms and controls, Geoderma, 74, 65-105, doi:10.1016/S0016-7061(96)00036-5, 1996.

Sparks, D., Page, A., Helmke, P., and Loeppert, R.: Methods of Soil Analysis, Part 3 - Chemical Methods, Soil Science Society of America Inc., Madison, DE, USA, 1996.

Srinivasarao, C., Lal, R., Kundu, S., Babu, M. B. B. P., Venkateswarlu, B., and Singh, A. K.: Soil carbon sequestration in rainfed production systems in the semiarid tropics of India, Sci. Total Environ., 487, 587-603, 2014.

Swindale, L. D.: Challenges and future strategies for managing red and lateritic soils in the Tropics and Subtropics, in: Red and Lateritic Soils, vol. 1, edited by: Sehgal, J., Blum, W. E., and Gajbhiye, K. S., Oxford and IBH Publishing CO.P.V.T. LTD, New Delhi, India, 419-432, 1998.
Turgut, B. and Aksakal, E. L.: Eects of sorghum residues and farmyard manure applications on soil erodibility parameters, Artvin Çoruh University, Faculty of Forestry Journal, 11, 1-10, 2010.

Ubalde, J. M., Sort, X., and Poch, R. M.: How soil forming processes determine soil-based viticultural zoning in Catalonia, Spain, in: Proceedings of the 19th World Congress of Soil Science, Brisbane, Australia, 1-6 August 2010, 1.4.2, 5-9, 2010.

Wachsmann, N., Norton, R., and Jochinke, D.: An update on the role and agronomy of safflower in southern Australia, global issues paddock action, in: Proceedings of the 14th Australian Agronomy Conference, Adelaide, South Australia, 21-25 September 2008.

Wan, Y., Lin, E., Xiong, W., Li, Y. E., and Guo, L.: Modeling the impact of climate change on soil organic carbon stock in upland soils in the 21st century in China, Agr. Ecosyst. Environ., 141, 23-31, 2011.

Wang, L., Tong, Z., Liu, G., and Li, Y.: Characterization of biomass residues and their amendment effects on water sorption and nutrient leaching in sandy soil, Chemosphere, 107, 354-359, doi:10.1016/j.chemosphere.2013.12.088, 2014.

Valpassos, M. A. R., Cavalcante, E. G. S., Cassiolato, A. M. R., and Alves, M. C.: Effects of soil management systems on soil microbial activity, bulk density and chemical properties, Pesqui. Agropecu. Bras., 36, 1539-1545, doi:10.1590/S0100204X2001001200011, 2001.

Yu, Y. and Jia, Z. Q.: Changes in soil organic carbon and nitrogen capacities of Salix cheilophila Schneid along a revegetation chronosequence in semi-arid degraded sandy land of the Gonghe Basin, Tibet Plateau, Solid Earth, 5, 1045-1054, doi:10.5194/se5-1045-2014, 2014.

Zhengchao, Z., Zhuoting, G., Zhouping, S., and Fuping, Z.: Effects of long-term repeated mineral and organic fertilizer applications on soil organic carbon and total nitrogen in a semiarid cropland, Eur. J. Agron., 45, 20-26, 2013. 